University of Nebraska - Lincoln

DigitalCommons@University of Nebraska - Lincoln

Faculty Publications in the Biological Sciences

Papers in the Biological Sciences

2002

\title{
Clone Size of Andropogon gerardii Vitman (Big Bluestem) at Konza Prairie, Kansas
}

\author{
Kathleen H. Keeler \\ University of Nebraska - Lincoln, kkeeler1@unl.edu \\ Charles F. Williams \\ Idaho State University \\ Linda S. Vescio \\ University of Nebraska-Lincoln
}

Follow this and additional works at: https://digitalcommons.unl.edu/bioscifacpub

Part of the Biodiversity Commons, Botany Commons, Plant Biology Commons, Plant Breeding and Genetics Commons, and the Terrestrial and Aquatic Ecology Commons

Keeler, Kathleen H.; Williams, Charles F.; and Vescio, Linda S., "Clone Size of Andropogon gerardii Vitman (Big Bluestem) at Konza Prairie, Kansas" (2002). Faculty Publications in the Biological Sciences. 298. https://digitalcommons.unl.edu/bioscifacpub/298

This Article is brought to you for free and open access by the Papers in the Biological Sciences at DigitalCommons@University of Nebraska - Lincoln. It has been accepted for inclusion in Faculty Publications in the Biological Sciences by an authorized administrator of DigitalCommons@University of Nebraska - Lincoln. 


\title{
Clone Size of Andropogon gerardii Vitman (Big Bluestem) at Konza Prairie, Kansas
}

\author{
KATHLEEN H. KEELER ${ }^{1,2}$ CHARLES F. WILLIAMS ${ }^{3}$ AND LINDA S. VESCIO ${ }^{2}$ \\ ${ }^{2}$ School of Biological Sciences, University of Nebraska-Lincoln, Lincoln 68588 \\ ${ }^{3}$ Department of Biological Sciences, Idaho State University, Pocatello 83209
}

\begin{abstract}
Clone size of plants of Andropogon gerardii from Konza Prairie Biological Station, Manhattan, Kansas was estimated from spatial patterns of genetic variation, using proteins detected by starch gel electrophoresis and DNA content (ploidy) measured by flow cytometry. Unique multi-locus protein banding patterns and differences in ploidy were used to exclude plants as members of the same clone. Individual clones averaged about $2 \mathrm{~m}$ in diameter and areas of prairie of $100 \mathrm{~m}^{2}$ were calculated to contain an average of 31.8 genetic individuals.
\end{abstract}

\section{INTRODUCTION}

Clonal growth, broadly defined, is found in $60-70 \%$ of plant species (Klimes et al., 1997). Clonal growth allows an individual to preempt space and is recognized as especially important in competitive habitats or situations (Cook, 1985; Klimes et al., 1997). Many of the dominant plants of North American prairies can form extensive clones (e.g., Weaver, 1968). However, clone size in prairie species is poorly documented.

Some clonal plant species have very large and very old clones, e.g., Gaylussacia brachycerium $1980 \mathrm{~m}$ diam, Aspen tremuloides $81 \mathrm{~m}$ diam and the grass Festuca rubra $220 \mathrm{~m}$ diam (Cook, 1985). Many of these large clones are estimated to be very old, e.g., for the species cited, 13,000+ y 10,000+ and $1000+$, respectively (Cook, 1985). The adaptations of huge old individuals must be in marked contrast to the adaptive responses of populations of short-lived individuals, which may be closely tracking changes in their environment (e.g., Linhart and Grant, 1996). While some clonal species certainly form large ancient clones, in general, populations of clonal plants are quite diverse genetically, composed of multiple genotypes (Ellstrand and Roose, 1987; Hamrick and Godt, 1990).

When Europeans arrived tallgrass prairie extended from western Ohio to eastern Nebraska and from southern Canada to Texas (Risser et al., 1981; Samson and Knopf, 1996). Andropogon gerardii dominated this grassland, forming $60 \%$ of the biomass on the uplands and nearly 100\% in lowlands and after fire (Weaver and Fitzpatrick, 1934; Svejcar, 1990). Beyond the tallgrass prairie biome, A. gerardii's range extends from the Atlantic Coast to the base of the Rocky Mountains and from southernmost Canada to the Gulf of Mexico. Despite its importance as an ecosystem dominant (Weaver and Fitzpatrick, 1934; Risser et al., 1981; Hartnett and Fay, 1998), little is known of its population biology. It is so abundant in many places that it forms a virtually continuous sward, making the study of individuals very difficult.

It has been suggested that Andropogon gerardii clones are on the order of $10 \mathrm{~s}$ to $100 \mathrm{~s}$ of meters in diameter (Reichman, 1987; Glenn-Lewin et al., 1990). Gustafson et al. (1999) published the first paper using DNA markers to look at A. gerardii genetic structure and found much within population variation in relict populations, suggestive of clones meters but not 100s of meters in diameter. This is consistent with our previous observations: mean

\footnotetext{
${ }^{1}$ Corresponding author: e-mail: kkeeler1@unl.edu
} 
clone area in the City of Boulder Open Space, Boulder, Colorado, was approximately 0.20 $\mathrm{m}^{2}$ (Keeler and Davis, 1999).

One goal of evaluating clone size is a better appreciation of how plants, in this case an ecosystem dominant, respond to the variable midcontinent environment. To understand response to the environment, it is of interest to know if there are a few outstanding genotypes which do well under most environmental conditions or if populations are genetically diverse, turning over rapidly and thereby tracking environmental change or if reality lies somewhere in between.

We used protein variation and ploidy level as genetic markers to estimate clone size and diversity for the tallgrass prairie dominant Andropogon gerardii (big bluestem) at Konza Prairie, Manhattan, Kansas.

\section{Methods AND MATERIALS}

Study sites and sampling procedures. - The clonal structure of Andropogon gerardii populations was studied at Konza Prairie Biological Station, Manhattan, Kansas. Konza is an unplowed tallgrass prairie of 3487 ha in the Kansas Flint Hills, managed by Kansas State University (Knapp and Seastedt, 1998). Plants used in a previous study of cytotypic variation at Konza Prairie (Keeler, 1992) were propagated from rhizomes and maintained in the greenhouse at the University of Nebraska-Lincoln. Data on protein variation and polyploidy among plants from six of the previously studied plots are reported in this paper (Table 1). The plots represent various environments and treatments at Konza: three plots (UBD, UBW, UDW) were in long-term unburned areas while three plots (1CD, NAD, NCD) were annually burned. Four of the plots were in the dry uplands of the prairie (1CD, UBD, NAD and NCD) and two were at the base of the hills where water tends to drain (UBW, UDW). Although NAD and NCD now are grazed by bison, the plants were sampled before the bison had much impact.

Plot areas were established to encompass at least 22 clumps of Andropogon gerardii. Each clump analyzed was at least $1 \mathrm{~m}$ from the others. Since $A$. gerardii density varied, plots covered from 23 to $63.5 \mathrm{~m}^{2}$ (Table 1). The closest two plots were more than $50 \mathrm{~m}$ apart and most were considerably more distant from neighboring plots.

Genetic analysis and clone assignment.-To distinguish individuals, unique electrophoretic phenotypes were identified using starch gel electrophoresis of enzymes. Leaf and root tissue from greenhouse grown plants supplied proteins for electrophoresis. Polymorphic enzymes used for exclusion were alcohol dehydrogenase $(\mathrm{ADH})$, colorimetric esterase (CE), diaphorase (DIA), peroxidase (PER) and phosphoglucoisomerase (PGI). Stain recipes were slight modifications those of Soltis et al. (1983) and North Carolina Agricultural Research Service (1988). Banding patterns were more intense and better resolved from leaf tissue for all enzymes except $\mathrm{ADH}$. ADH activity and resolution was best from root tissue.

All tissues were ground in 4-5 drops of extraction buffer with an ice cold mortar and pestle. The extraction buffer used for $\mathrm{CE}$ and PER was $1 \mathrm{M}$ Tris-HCl $\mathrm{pH} 7.1$ with $0.1 \% \mathrm{w} /$ $\mathrm{v}$ PVP-40. DIA and some PGI samples were crushed in $1.0 \mathrm{~g} \mathrm{~L}$-ascorbic acid, sodium salt and $2.0 \mathrm{~g}$ sucrose dissolved in $9.0 \mathrm{ml}$ distilled water. Samples assayed for $\mathrm{ADH}$ and some PGI samples were ground in the extraction buffer of Williams and Waser (1999). All enzymes were best resolved in $10-11 \%$ horizontal starch gels using the citrate-borate buffer system \#6 of Soltis et al. (1983). Gels were cooled with ice packs and run at 35-50 mA until the front had moved anodally $8 \mathrm{~cm}$.

Because of the high polyploid level of Andropogon gerardii (Norrmann et al., 1997), genetic interpretation of enzyme electromorphs is difficult. For the purposes of this study we grouped all the bands of a stain system into a single electrophoretic phenotype for each 


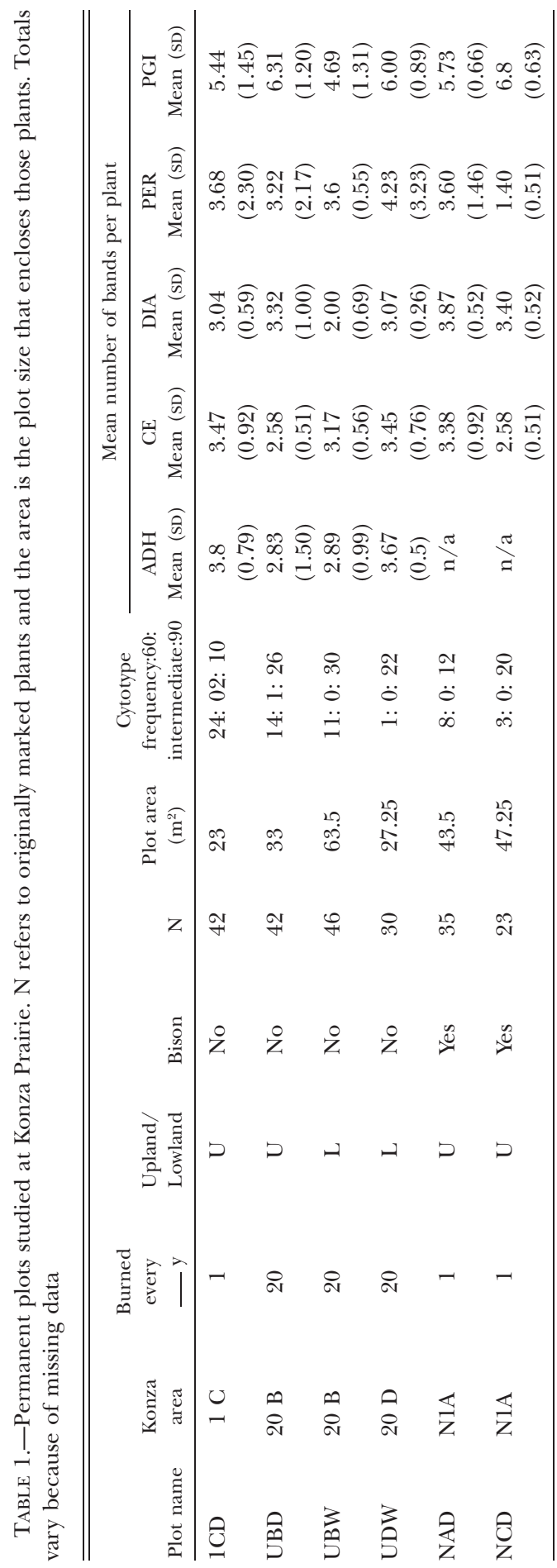


TABLE 2.-Electrophoretic phenotypes in Andropogon gerardii at Konza Prairie

\begin{tabular}{|c|c|c|c|c|c|c|c|}
\hline Enzyme & $\begin{array}{c}\text { Total } \\
\text { number } \\
\text { of bands }\end{array}$ & $\begin{array}{l}\text { Bands per } \\
\text { plant Mean } \\
\text { (SD) }\end{array}$ & $\begin{array}{c}\text { Range of } \\
\text { bands/plant } \\
(\mathrm{N})\end{array}$ & $\begin{array}{l}\text { Number of } \\
\text { phenotypes }\end{array}$ & $\begin{array}{l}\text { Phenotypes } \\
\text { occurring in } \\
\text { all of plots } \\
\text { compared }\end{array}$ & $\begin{array}{c}\text { Number } \\
\text { in only } 1 \\
\text { plot of } \\
\text { plots } \\
\text { compared }\end{array}$ & $\begin{array}{l}\text { Number of } \\
\text { plots } \\
\text { compared } \\
\text { (Number of } \\
\text { plants) }\end{array}$ \\
\hline $\mathrm{ADH}$ & 10 & $\begin{array}{c}3.54 \\
(1.27)\end{array}$ & $\begin{array}{c}1-7 \\
(158)\end{array}$ & 12 & 0 & 3 & $\begin{array}{c}6 \\
(94)\end{array}$ \\
\hline $\mathrm{CE}$ & 11 & $\begin{array}{c}3.07 \\
(0.83)\end{array}$ & $\begin{array}{c}2-5 \\
(140)\end{array}$ & 27 & 0 & 21 & $\begin{array}{c}6 \\
(108)\end{array}$ \\
\hline DIA & 6 & $\begin{array}{c}3.07 \\
(0.86)\end{array}$ & $\begin{array}{l}1-6 \\
(98)\end{array}$ & 20 & 0 & 13 & $\begin{array}{c}6 \\
(98)\end{array}$ \\
\hline PER & 14 & $\begin{array}{c}3.38 \\
(1.74)\end{array}$ & $\begin{array}{c}1-8 \\
(147)\end{array}$ & 74 & 0 & 64 & $\begin{array}{c}5 \\
(136)\end{array}$ \\
\hline PG1 & 11 & $\begin{array}{c}5.66 \\
(1.3)\end{array}$ & $\begin{array}{c}3-9 \\
(142)\end{array}$ & 32 & 0 & 28 & $\begin{array}{c}5 \\
(61)\end{array}$ \\
\hline
\end{tabular}

individual based on the presence or absence of bands. These multilocus electrophoretic phenotypes were compared among sampled plants. If there is little genetic variation in the population, this technique will underestimate the number of genetic individuals and overestimate the extent of clones. In contrast, nongenetic effects on protein expression may increase the variation in phenotypic banding patterns and could obscure the genetic similarity of neighboring plants. Although nongenetic variation was not studied, the plants compared were growing under uniform conditions (i.e., in the same greenhouse bay) which minimized environmental variation. We did not compare phenotypes between plots except: (1) to present the number of phenotypes shared between plots (Columns 6, 7 in Table 2) and (2) to indicate that individuals' phenotypes within a plot were similar, despite differing ploidy levels (Table 3).

For all plants chromosome number was determined by flow cytometry (Keeler et al., 1987; Norrmann et al., 1997). This provided an additional genetic character, ploidy, since plants with different chromosome numbers are assumed to be different genetic individuals. Flow cytometry determines chromosome number by measuring the amount of fluorescently stained nuclear DNA passing in front of a laser. The amount of DNA stained correlates with chromosome number (e.g., Michaelson et al., 1991). At Konza most Andropogon gerardii individuals have 60 chromosomes, which gives a characteristic value of 5.93 pg DNA (+/ $-0.52,95 \% \mathrm{cl}$ ) per nucleus using propidium iodide as the DNA stain (Norrmann et al., 1997). Approximately $45 \%$ of Konza plants (but up to $96 \%$ within a plot) had 8.92 pg DNA/nucleus (+/-0.48), representing 90-chromosome plants (Keeler et al., 1987; Norrmann et al., 1997). The peaks of DNA produced by the flow cytometer for these cytotypes are narrow and do not overlap (Keeler et al., 1987; Michaelson et al., 1991). A few individuals $(<5 \%$ of the 500 studied by Keeler, 1992) had an intermediate amount of DNA. These are aneuploids, produced by crosses between the 60 and 90 chromosome cytotypes (Norrmann et al., 1997). All A. gerardii cytotypes are interfertile, although fertility of plants with more than 60 chromosomes is reduced by production of gametes with unbalanced chromosome complements (Norrmann et al., 1997).

Clone extent was determined by excluding plants as members of the same clone if they differed in either protein banding pattern or DNA content. To decide if plants of the same 


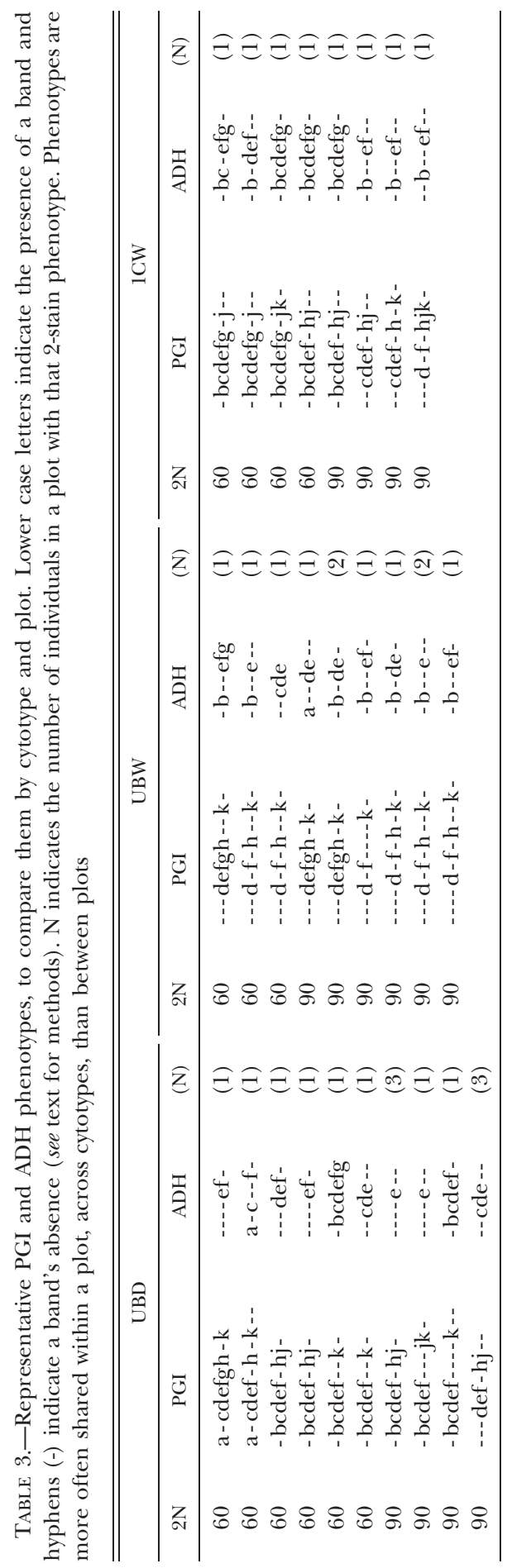


TABLE 4.-Andropogon gerardii clone size estimates, Konza Prairie, KS. Overall mean calculated by combining values independent of plot, not as mean of means

\begin{tabular}{|c|c|c|c|c|c|}
\hline Plot & $\begin{array}{l}\text { Number of } \\
\text { phenotypes }\end{array}$ & $\begin{array}{l}\text { Mean no. } \\
\text { observed pts/ } \\
\text { clone (SD) } \\
\text { [largest] }\end{array}$ & $\begin{array}{c}\text { Mean clone } \\
\text { dimensions }(\mathrm{m})(\mathrm{SD}) \\
\text { [largest diameter } \\
\text { in plot }]\end{array}$ & $\begin{array}{l}\text { Mean clone } \\
\text { area }\left(\mathrm{m}^{2}\right) \\
(\mathrm{sD})[\text { largest } \\
\text { clone] }\end{array}$ & $\begin{array}{c}\text { Mean number } \\
\text { of clones } \\
\text { in } 10 \mathrm{~m}^{2}\end{array}$ \\
\hline $1 \mathrm{CD}$ & 22 & $\begin{array}{l}1.5(0.80) \\
{[4]}\end{array}$ & $\begin{array}{l}2.16 \times 1.30(1.82,0.67) \\
{[6.8]}\end{array}$ & $\begin{array}{l}2.12(1.88) \\
{[8.1]}\end{array}$ & 10.45 \\
\hline UBD & 22 & $\begin{array}{l}1.70(1.49) \\
{[7]}\end{array}$ & $\begin{array}{l}2.32 \times 1.61(1.82,0.93) \\
{[8.5]}\end{array}$ & $\begin{array}{l}3.31(3.05) \\
{[9.4]}\end{array}$ & 16.50 \\
\hline UBW & 20 & $\begin{array}{l}2.20(1.60) \\
{[5]}\end{array}$ & $\begin{array}{l}3.78 \times 5.59(3.43 \times 2.45) \\
{[10.7]}\end{array}$ & $\begin{array}{l}4.61(4.66) \\
{[17.6]}\end{array}$ & 31.75 \\
\hline UDW & 11 & $\begin{array}{l}2.00(1.61) \\
{[6]}\end{array}$ & $\begin{array}{l}3.11 \times 1.73(2.84,1.12) \\
{[4.5]}\end{array}$ & $\begin{array}{l}4.04(3.67) \\
{[10.8]}\end{array}$ & 24.77 \\
\hline NAD & 30 & $\begin{array}{l}1.13(0.35) \\
{[3]}\end{array}$ & $\begin{array}{l}1.72 \times 1.24(0.75,0.59) \\
{[3.25]}\end{array}$ & $\begin{array}{l}2.45(2.44) \\
{[10.6]}\end{array}$ & 15.00 \\
\hline NCD & 14 & $\begin{array}{l}1.50(0.94) \\
{[3]}\end{array}$ & $\begin{array}{l}2.37 \times 1.45(1.24,0.63) \\
{[9.75]}\end{array}$ & $\begin{array}{l}3.94(3.50) \\
{[10.7]}\end{array}$ & 42.95 \\
\hline Mean (SD) & 12.4 & $1.59(1.15)$ & $2.47 \times 1.62(2.17 \times 1.31)$ & $3.20(3.24)$ & 31.77 \\
\hline
\end{tabular}

ploidy level were different, a conservative approach was used: identity was assumed unless they differed by two well defined, darkly staining bands.

\section{RESULTS}

Protein and cytotype variation in Andropogon gerardii. - Of the stain systems studied, DIA and ADH were the least variable, PER the most. The total number of different bands observed per stain ranged from 6 (DIA) to 14 (PER), while the number of phenotypic combinations varied from 12 (ADH) to 74 (PER) (Table 2). For PER we scored only the anodally migrating bands. For CE two very fast bands migrated with the front under our standard conditions and were not scored. The number of bands per individual plant expressed for any enzyme specific stain ranged from 1-9, averaging about 3 for all stains except PGI, which averaged 5.7 (Table 2). Although quaternary structure, number of loci and alleles cannot be determined with certainty without formal genetic analysis of crosses, the small minimum number of bands per individual suggests that only 1 or 2 loci with multiple alleles are expressed in hexaploid $A$. gerardii (Tables 2, 3).

There was a great deal of electrophoretically detectable variation among plants sampled since most plants had multiple bands for each enzyme and differed from their neighbors (Tables 2, 3). Banding patterns, e.g., ADH and PGI phenotypes (Table 3), were generally more similar between ploidy levels within plots than among plants of the same ploidy between plots. Local variation is further seen because there is no common phenotype found in all plots (Table 4) and many phenotypes are seen only within one plot (Table 4). Despite the insensitivity of number of bands per plant as a character, for every stain system, the extremes in mean number of bands per plot are statistically significantly different (e.g., for PGI, NCD has significantly more bands than UBW, see Table $1, t$-test, $\mathrm{P}<0.0001$ (SAS Institute Inc., 1999).

Clone sizes. - On average, each phenotype was recorded from an average of $1.59(\mathrm{SD}=$ 1.15) plants (Table 4). Since plants were sampled approximately every meter, clone size rarely exceeded $2 \mathrm{~m}$. If the area were filled only with Andropogon gerardii and the plants 
a)

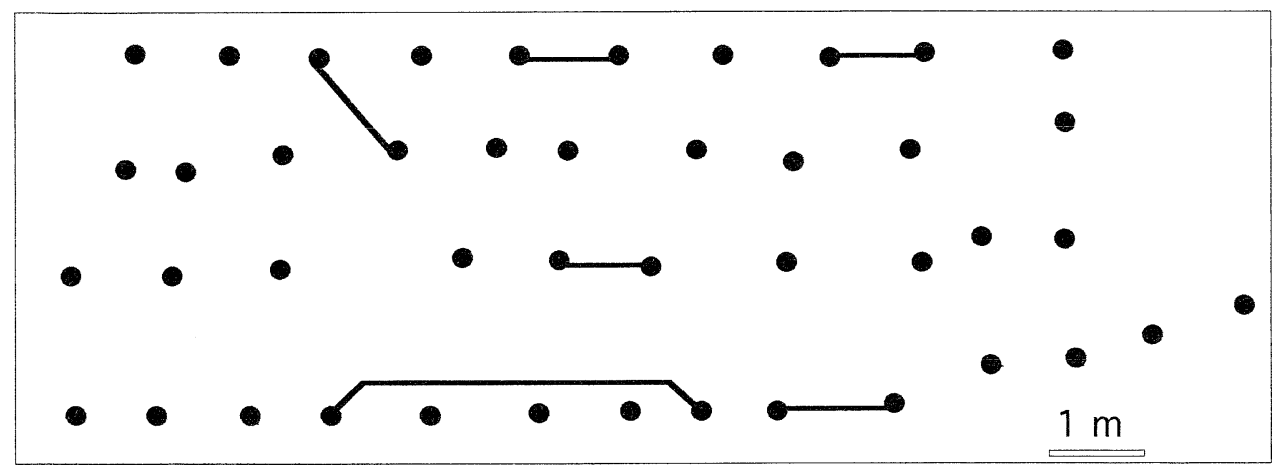

b)

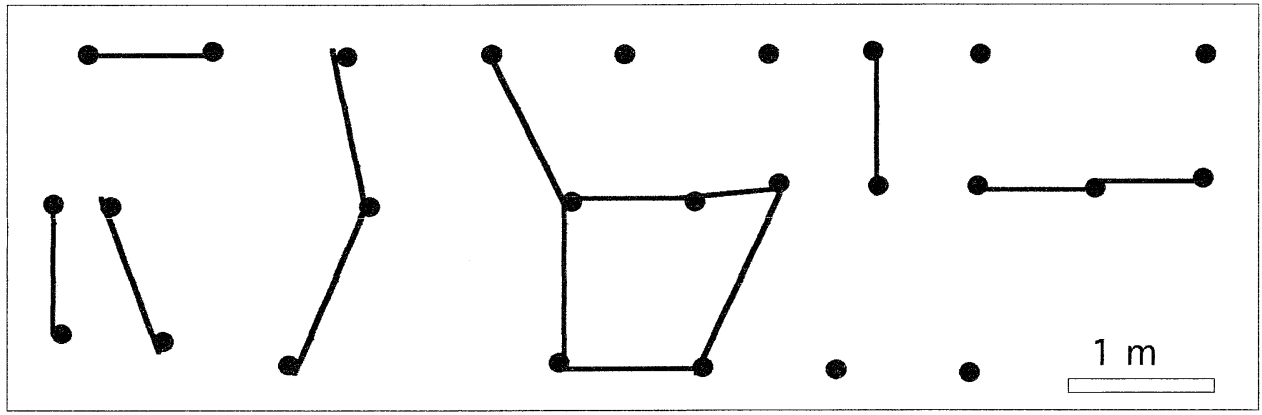

FIG. 1.-Distribution of Andropogon gerardii clones in two plots at Konza Prairie. Every dot represents an A. gerardii plant. Those connected by a line have identical phenotypes, based on protein electrophoresis and DNA content (a) Plot NAD, (b) Plot UDW

were uniform size, each clone would be $1.95 \mathrm{~m}^{2}$, and if circular, $1.4 \mathrm{~m}$ in diameter. However, there are other plant species between the A. gerardii clumps, despite the fact that A. gerardii dominates the canopy (nicely illustrated in Fig. 5 of Weaver and Fitzpatrick, 1934), so this is a maximum estimate of area occupied. In a few cases plants several meters apart and separated by plants from other clones have identical phenotypes (e.g., Fig. 1).

\section{DISCUSSION}

There is great genetic variation in Andropogon gerardii, as might be expected from a polyploid complex (Tables 1, 2, Fig. 1). There is generally more similarity within than between plots (Tables 3,4). Individuals in local groups (plots) interbreed across ploidy levels, as indicated by intercytotype hybridization (Norrmann et al., 1997) and shared phenotypes (Table 3).

As a rhizomatous grass, Andropogon gerardii is potentially immortal and capable of spreading over large areas. That is not the case at Konza. By excluding plants from clone membership based on electrophoretic banding patterns and polyploidy, we found that the average $100 \mathrm{~m}^{2}$ area of this unplowed tallgrass prairie contained 31.8 different genetic indi- 
viduals (Table 4). Stated another way, each clone appeared an average of 1.59 times per plot (plots average $39.4 \mathrm{~m}^{2}$ ) (Tables 1,4).

Although typically small, a few clones were quite extensive. Furthermore, we cannot exclude the possibility that clones extend beyond the plot boundaries. Additional data is required to determine whether distant indistinguishable phenotypes represent an old fragmented clone or distinct genetic individuals that do not differ for the characters tested. On the whole, we are most likely to overestimate clone size, since close relatives may not differ for the traits scored.

Little has been published on the growth of Andropogon gerardii clones. In tallgrass prairies sites in Boulder, Colorado, isolated clones shifted their position only a few $\mathrm{cm} / \mathrm{y}$ (Keeler and Davis, 1999). It may require decades for clones to migrate very far across a prairie.

Weaver and colleagues (Weaver and Fitzpatrick, 1934; Weaver and Albertson, 1936, 1943) reported that Andropogon gerardii and other tallgrasses died off the hilltops in Nebraska during the Great Drought of the 1930s, and that seed recruitment by A. gerardii was very high at the end of the drought. Today, A. gerardii covers the hilltops at Nine-Mile Prairie, one of the sites studied by Weaver (Keeler, 1992). This record of death in dry periods, reseeding after droughts, and slow clonal expansion, is consistent with the modest clone sizes found at Konza Prairie.

Clone sizes are rarely mentioned in publications on clonal species (but see reviews in Jackson et al., 1985). For most species, the discontinuous distribution of the plants allows determination of maximum clone sizes relatively easily and is probably so evident to the workers as to elicit no comment. Because Andropogon gerardii forms a virtually continuous matrix across the tallgrass prairie (Collins, 1992; Glenn and Collins, 1992), visual estimation of clone size is problematic. Thus, this is the first report estimating clone size for this species. We find the clones are surprisingly small.

Molecular studies indicate substantial genetic variation within populations of clonal species (e.g., Ellstrand and Roose, 1987; Hamrick and Godt, 1990, but see Eckert, 1999). Publications specifically looking at clone size emphasize variation in clone size in relation to habitat. For example, Silander (1979) found clones of the grass Spartina patens reached a maximum diameter of $10.3 \mathrm{~m}$. However, populations on dunes were dominated by a few relatively large clones while marsh populations had smaller, more genetic diverse clones. Thus, clone size was a function of habitat. For the rare shrub Neviusia alabamensis, local populations at the edge of the range appear to contain only a single clone, covering as much as $4300 \mathrm{~m}^{2}$ (Freiley, 1994). One would expect more individuals per population and probably smaller clone sizes in Neviusia within the main part of its range, where the environment is more suitable.

Clone sizes for Andropogon gerardii at Konza Prairie are relatively small. Konza is a large unplowed tallgrass prairie, managed to approximate historical conditions. Clone sizes here should be representative, at least, of the region.

Konza Prairie is on the western edge of the tallgrass prairie biome and on the distinctive soils of the Kansas Flint Hills (Knapp and Seastedt, 1998). What we found at Konza Prairie is consistent with observations from Nine-Mile Prairie in Lincoln, Nebraska (Weaver and Albertson, 1936, 1943; Keeler, 1990), a 91.6 ha remnant on glaciated loess soil. The Konza clone sizes are also consistent with clone sizes observed in the City of Boulder Open Space (Keeler and Davis, 1999), where Andropogon gerardii occurs in a narrow zone of tallgrass prairie that runs along the base of the Rocky Mountains (Livingston, 1952; Branson et al., 1965). None of these populations are in the middle of the tallgrass prairie region but unfortunately virtually no large remnants of eastern tallgrass prairie still exist (Steinauer and Collins, 1996). In the western part of the tallgrass prairie relatively small clone sizes 
are common. This is a droughty environment of recurrent extinction and recolonization. Conditions in the moister, more climatically stable, eastern tallgrass prairie (now almost entirely gone) may have allowed greater clonal spread.

The high level of small-scale genetic variation indicates a high frequency of sexual reproduction. Even though at Konza Andropogon gerardii is far more abundant than any other plant, the clones average 2.47 by $1.62 \mathrm{~m}$ in diameter with a mean area of $3.20 \mathrm{~m}^{2}$. Thus, A. gerardii dominates Konza Prairie with a large number of genetically diverse individuals, rather than a few highly successful genotypes. While some individuals may be very old, it is probable that this species tracks environmental change by relative success and failure of individual clones, recolonizing by seed after droughts and other disasters.

Acknowledgments. - This research was supported in part by NSF BSR-8704705, NSF BSR-9400471, the University of Nebraska-Lincoln Research Council and U. Nebraska Center for Biotechnology Minigrant. We thank J. R. Curtiss, R. L. Miller and J. Austin for electrophoretic help and K. Harkins for flow cytometry. We are grateful to Konza Prairie LTER for logistic support.

\section{Literature Cited}

Branson, F. A., R. F. Miller And I. S. McQueen. 1965. Plant communities and soil moisture relationships near Denver, Colorado. Ecology, 46:311-319.

Collins, S. L. 1992. Fire frequency and community heterogeneity in tallgrass prairie vegetation. Ecology, 73:2001-2006.

Cook, R. E. 1985. Growth and development in clonal plant populations, p. 259-296. In: J. B. C. Jackson, L. W. Buss and R. E. Cook (eds.). Population biology and evolution of clonal plants. Yale University Press, New York.

ECKert, C. G. 1999. Clonal plant research: proliferation, integration, but not much evolution. Am. J. Bot., 86:1649-1654.

Ellstrand, N. C. And M. L. Roose. 1987. Patterns of genotypic diversity in clonal plant species. Am. J. Bot., 74:123-131.

FreILEY, K. J. 1994. Clonal diversity patterns in marginal populations of the geographically restricted shrub Neviusia alabamensis (Rosaceae). Southwest Nat., 39:34-39.

GLenN, S. M. AND S. L. Collins. 1992. Effects of scale of disturbance on rates of immigration and extinction of species in prairies. Oikos, 63:273-280.

Glenn-Lewin, D. C., L. A. Johnson, T. W. Jurik, A. Akey, M. Leoschke and T. Rosburg. 1990. Fire in central North American grasslands: vegetative reproduction, seed germination and seedling establishment, p. 28-45. In: S. L. Collins and L. L. Wallace (eds.). Fire in North American tallgrass prairies. University of Oklahoma Press, Norman, Oklahoma.

Gustafson, D. J., D. J. Gibson And D. L. NiCKRENT. 1999. Random amplified polymorphic DNA variation among remnant big bluestem (Andropogon gerardii Vitman) populations from Arkansas' Grand Prairie. Molec. Ecol., 8:1693-1701.

Hamrick, J. L. And M. J. W. Godt. 1990. Allozyme diversity in plant species, p. 43-63. In: A. D. H. Brown, M. T. Clegg, A. L. Kahler and B. S. Weir (eds.). Plant population genetics, breeding and genetic resources. Sinauer Associates Inc., Sunderland, MA.

Hartnett, D. C. And P. A. Fay. 1998. Plant populations. Patterns and processes, p. 81-100. In: A. K. Knapp, J. M. Briggs, D. C. Hartnett and S. L. Collins (eds.). Grassland dynamics. Long-term ecological research in tallgrass prairie. Oxford University Press, New York.

Jackson, J. B. C., L. W. Buss And R. E. CoOK (EDS.). 1985. Population biology and evolution of clonal organisms. Yale University Press, New York. 530 p.

KeELER, K. H. 1990. Distribution of polyploids in big bluestem (Andropogon gerardii Poaceae) across the tallgrass prairie region. Genome, 33:95-100.

1992. Local polyploid variation in the native prairie grass Andropogon gerardii. Am. J. Bot., 79: 1229-1232.

AND G. L. DAVIS. 1999. Comparison of common cytotypes of Andropogon gerardii (Andropogoneae, Poaceae). Am. J. Bot., 86:974-979. 
B. Kwankin, P. W. Barnes And D. W. Galbraith. 1987. Polyploid polymorphism in Andropogon gerardii Vitman (Poaceae). Genome, 29:374-379.

Kuimes, L., J. Klimesova, R. Hendricks and J. van Groenendael. 1997. Clonal plant architecture: a comparative analysis of form and function, p. 1-29. In: H. de Kroon and J. van Groenendael (eds.). The ecology and evolution of clonal plants. Backhuys Publishers, Leiden, The Netherlands.

KnapP, A. K. AND T. R. SEAstedt. 1998. Introduction: Grasslands, Konza Prairie and long-term ecological research, p. 3-15. In: A. K. Knapp, J. M. Briggs, D. C. Hartnett and S. L. Collins (eds.). Grassland dynamics. Long-term ecological research in tallgrass prairie. Oxford University Press, New York.

LinhaRT, Y. B. AND M. C. GRANT. 1996. Evolutionary significance of local genetic differentiation in plants. Annu. Rev. Ecol. Syst., 27:237-277.

Livingston, R. B. 1952. Relict true prairie communities in central Colorado. Ecology, 33:72-86.

Michaelson, M. J., H. J. Price, J. R. Ellison and J. S. Johnston. 1991. Comparison of plant DNA contents determined by Feulgen microspectrophotometry and laser flow cytometry. Am. J. Bot., 78:590-593.

Norrmann, G. A., C. A. Quarín ANd K. H. Keeler. 1997. Evolutionary implications of meiotic chromosome behavior, reproductive biology and hybridization in $6 \times$ and $9 \times$ cytotypes of Andropogon gerardii (Poaceae). Am. J. Bot., 84:201-207.

North Carolina Agricultural Research Service. 1988. Techniques and scoring procedures for starch gel electrophoresis of enzymes from maize (Zea mays L.). North Carolina State University, Raleigh, North Carolina. 87 p.

Reichman, O. J. 1987. Konza Prairie. A tallgrass natural history. University Press of Kansas, Lawrence, KS. 226 p.

Risser, P. G., E. C. Birney, H. D. Blocker, S. W. May, W. J. Parton and J. A. Wiens. 1981. The true prairie ecosystem. Hutchinson Ross Publishing Co., Stroudsburg, PA. 557 p.

Samson, F. B. AND F. L. Knopf (EDS.). 1996. Prairie conservation. Island Press, Washington, D.C. 339 p.

SAS Institute InC. 1999. StatView Statistical Program. SAS Institute Inc, Cary, NC.

Silander, J. A. 1979. Microevolution and clone structure in Spartina patens. Science, 203:658-660.

Soltis, D. E., C. H. Haufler, D. C. Darrow AND G. J. Gastony. 1983. Starch gel electrophoresis of ferns: a compilation of grinding buffers, gel and electrode buffer, and staining schedules. $\mathrm{Am}$. Fern J., 73:9-27.

Steinauer, E. M. And S. L. Collins. 1996. Prairie ecology-the tallgrass prairie, p. 39-52. In: F. B. Samson and F. L. Knopf (eds.). Prairie conservation. Island Press, Washington, D.C.

SveJCAR, T. J. 1990. Response of Andropogon gerardii to fire in the tallgrass prairie, p. 19-27. In: S. L. Collins and L. L. Wallace (eds.). Fire in North American tallgrass prairies. University Oklahoma Press, Norman, OK.

Weaver, J. E. 1968. Prairie plants and their environment. University of Nebraska Press, Lincoln, NE. $276 \mathrm{p}$.

- AND F. W. Albertson. 1936. Effects of the great drought on the prairies of Iowa, Nebraska and Kansas. Ecol. Monogr., 17:567-639.

- AND — 1943. Resurvey of grasses, forbs and underground plant parts at the end of the great drought. Ecol. Monogr., 13:63-117. AND T. J. FitzPatrick. 1934. The prairie. Ecol. Monogr., 4:109-295.

Williams, C. F. AND N. M. WASER. 1999. Spatial genetic structure of Delphinium nuttallianum populations: inferences about gene flow. Heredity, 83:541-550. 